\title{
CEO CHARACTERISTICS AND ENVIRONMENTAL PERFORMANCE: EVIDENCE FROM INDONESIAN BANKS
}

\author{
Nurmadi Harsa Sumarta* \\ Doctoral Student of Environmental Science, Universitas Sebelas Maret, Indonesia \\ Muhammad Agung Prabowo \\ Faculty of Economics and Business, Universitas Sebelas Maret, Indonesia \\ Prihatnolo Gandhi Amidjaya \\ Faculty of Economics and Business, Universiti Malaysia Sarawak, Malaysia \\ Edy Supriyono \\ Faculty of Economics and Business, Universitas Sebelas Maret, Indonesia \\ Agista Putri Prameswari \\ Center for Fintech and Banking, Universitas Sebelas Maret, Indonesia
}

\begin{abstract}
Following the paradigm shift of company performance, from merely financial aspects to the balance between economics and environmental aspects, a study that explores the drivers of company environmental performance is indispensable. This study aims to empirically examine the role of CEO characteristics in determining the environmental performance from CEO's gender, age, expertise, and international experience in Indonesian banks. We use secondary data from banks' annual and sustainability reports that were analysed using panel data regression. The results demonstrate that CEO's international experience and education level positively affect bank's environmental performance while foreign CEO and CEO's abroad study exhibit negative effect. Our findings emphasise that CEO plays a great role in initiating banks' environmental activities. CEO's decision is crucial to adopt environmental practice that leads to better environmental performance. The study contributes to the Indonesian literature by providing empirical evidence of CEO factors in determining banks' environmental performance, in which there are very limited studies examining the role of CEO. We also suggest the Indonesian Financial Service Authority to encourage banks to deliver higher environmental contribution by maximizing the role of CEO.
\end{abstract}

Keywords: Environmental Performance, CEO Characteristics; Gender, Age, Expertise, International Experience.

Received: 27 November 2020

Accepted: 10 May 2021

https://doi.org/10.33736/ijbs.3779.2021

\footnotetext{
- Corresponding author: Doctoral Student of Environmental Science, Universitas Sebelas Maret, Jalan Ir. Sutami 36A, Surakarta, Indonesia 57126; Phone: +62 812-1919-1357; Email: nurmadi@staff.uns.ac.id
} 


\section{INTRODUCTION}

For the last few decades, the assessment of company performance has experienced a significant paradigm shift: not solely oriented towards economic growth (Tara et al., 2015). The paradigm shift is an adjustment in almost all types of industry (Feng \& Ru, 2019), that has occurred since the development of the triple bottom line concept by Elkington (1997). This concept is measured from three dimensions: profit, planet, and people. The triple bottom line is a concept applied to measure company performance in which banks has started realising its importance (Fernando \& Fernando, 2017), manifested as a part of sustainable finance framework. The adjustments made by the financial industry to achieve sustainability is by developing the financing and investment for sustainable development concept (Feng \& $\mathrm{Ru}, 2019$ ). This concept requires that the financial industry in addition to being profit-oriented (profit), must also contribute to creating the welfare of the people (people) and protecting the environment (planet) (Fernando \& Fernando, 2017). Fatemi and Iraj (2013) argue that an approach that only maximises money generating capability for shareholders from now on is no longer a valid guide to create sustainable wealth.

The concept of green investment and financing for sustainable development grows significantly for the past decade, increasing public concern on environmental-based finance as a part of environmental performance in financial industry (Scholtens, 2017). Sparkes (2002) also highlights the importance of various aspects of environmental performance that includes ethical, moral, and financial considerations through the screening stage as an investment philosophy. However, companies' environmental performance in several developing countries is still arguably below average, particularly in Indonesia (Siregar \& Bachtiar, 2010; Djajadikerta \& Trireksani, 2012).

Indonesia is a developing country gifted with greatly rich natural resources. However, Indonesia has been experiencing a lot of social and environmental issues (Gunawan, 2015). Ironically, numerous social and environmental cases in Indonesia are caused by non-responsible companies due to lack business ethics (Siregar \& Bachtiar, 2010), especially excessive deforestation, pollution and serious environmental damage. Therefore, it is urgently necessary for Indonesian companies to be more responsible for the impact of their business operation, particularly on the environment (Djajadikerta \& Trireksani, 2012). Even further, companies must have a proper contribution to solving environmental issues and support sustainable development (Sarumpaet et al., 2017).

Indonesian government actually pay a lot of attention to environmental issues, especially around 2010s. The Law Number 32 of 2009 concerning Environmental Protection and Management was issued in the end of 2009. Sustainable and Responsible Investment Index was also released in Indonesia Stock Exchange (IDX) that year. Further, Sustainability Reporting Award was also created in 2013 to present high appreciation to companies with great contribution to sustainability. Finally, in order to support environmental practice by Indonesian companies, the Indonesia Financial Service Authority (OJK) issues the Roadmap for Sustainable Finance in 2014, and later followed by OJK Regulation Number 51/POJK.03/2017 concerning Sustainable Finance. Through this regulation, OJK attempts to increase companies' contribution to sustainability, one of which is by having good environmental practices. Thus, Indonesian companies can deliver positive impact to its environment. In practice, OJK appoints the banking sector as the leading sector to initiate environmental practice, considering the fact that banking sector tend to be more compliant with 
regulations. Good environmental performance by banks will motivate other sectors. Therefore, examination on bank's environmental performance is necessary to evaluate the implementation.

Following the importance of companies' environmental performance for sustainable development (Boiral \& Henri, 2017), it is important to build research foundation that examines its determining factors. It is argued that environmental initiatives highly rely on company's organisational factors (Richter \& Arndt, 2018). The organisational component to realise proper environmental performance is required to apply the concept effectively (Volz, 2018). A company cannot act alone by itself as it does not have a will to run itself, therefore it requires people who have the will to run the company in line with the demands from its stakeholders (Lewis et al., 2014), including the achievement of environmental performance. In this matter, the role of business leaders is the most significant part (Shahab et al., 2019).

The main role of a leader is to achieve the mission of the company and fulfil the main goals of the company. A leader is capable of influencing changes and achievement of goals by encouraging the organisation members to reach high levels of achievement (Nelson, 2005). At the company level, certain qualities will help company leaders, especially the CEO, to improve company's performance (Peterson et al., 2012; Zuraik \& Kelly, 2019). The traits of the CEO are often seen as an early indicator of the board of directors' quality (Shahab et al., 2019). Furthermore, the leader qualities are a major factor of leadership and affect the leader-follower relationship, business practices, and the formation of organisational values.

Richter and Arndt (2018) mention that corporate social responsibility (CSR) engagement basically result from a cognitive process. Based on the perspective, the $\mathrm{CEO}$ has freedom in decision making and is, therefore, become a cause for a company to be involved in CSR. Researcher finds that companies are part of environmental development, therefore ethics and environmental-oriented responsibilities are needed in company activities (Friedman, 2007; Volz, 2018). Company activities that are oriented towards environmental issues are influenced by the personality of its CEO (Kim et al., 2018). The CEO personality can be seen in their characteristics. Several fundamental characteristics of CEO such as gender, age, expertise, and organisational experience will affect the environmental performance (De Young, 1996; Du \& Vieira, 2012; Ewert \& Baker, 2001; Gong, 2006; Huang, 2012; Kim et al., 2018; Manner, 2010; Prabowo et al., 2017; Smith, 1995; Stern et al., 1995). Therefore, our study will focus on the influence of the CEO's gender, age, expertise, and international experience on environmental performance in Indonesian banks.

Investigating CEO factors on environmental performance in Indonesian banks is important due to several gaps. In addition to low environmental performance issues (Amidjaya \& Widagdo, 2019; Djajadikerta \& Trireksani, 2012; Siregar \& Bachtiar, 2010), environmental performance studies in Indonesia are still dominated with broad governance factors at firm level (Amidjaya \& Widagdo, 2019; Prabowo et al., 2017, Siregar \& Bachtiar, 2010). There are still limited studies that examine individual level factors such as CEO characteristics in Indonesia. This study is among the earliest empirical studies in Indonesia that reveal comprehensively the impact of various CEO factors on bank's environmental performance. We extend the literature in Indonesian context by revealing the significance of CEO factors, in which several factors are less explored in previous studies namely $\mathrm{CEO}$ expertise and international experience. 


\section{LITERATURE REVIEW AND HYPOTHESIS DEVELOPMENT}

\subsection{Agency Theory}

Agency theory explains the relationship between the principal (owner/shareholder) and agent (the manager who manages a company) (Mantysaari, 2010). This theory assumes that there are opportunities for agency problems namely the occurrence of conflict of interest and differences in access to information (information asymmetry). Agency theory assumes that humans are individualistic and opportunistic. These characters result in the desire to always put personal interests as their priority and maximise their benefits. Further, it causes conflicts between individuals. The situation leads to the agency problem that becomes a basic element of a company's contractual relationship (Jensen \& Meckling, 1976; Fama \& Jensen, 1983). Jensen (1986) argues that a manager will take a project that will provide greater benefits for his/her interests (opportunistic behaviour) compared to the interests of investors. The agency relationship includes the relationship between managers and shareholders, or the relationship between managers and creditors (Scott, 2012).

The Carr and Brower's agency model (2000), assumes two choices in agency contracts: (1) behaviour-based, that is, principals must monitor agent's behaviour and (2) outcome-based; to achieve principals' interests there need to be incentives to motivate agents. Principals monitor the reporting process regularly, monitoring the agent's actions and performance results to manage the agency costs (Fama, 1980; Jensen \& Meckling, 1976; Shleifer \& Vishny, 1986). Zhou and Panbunyuen (2008) explain that agency costs that arise from agency problems can be overcome through monitoring mechanisms.

\subsection{Upper Echelon Theory}

Upper echelons theory is introduced by Hambrick and Mason (1984). Carpenter et al. (2004) argues that this theory has proven its reliability in examining the role of top management in dealing with business issues. In the context of a company, David et al. (2012) suggest that top managers will greatly influence performance in order to increase the sustainability, wealth and welfare of the company. Manner (2010) reveals that in practice, top managers with certain characteristics will be able to face a series of business issues and challenges with the right strategic policies. Following the rise of environmental issues and public demands for sustainability for the past decade, the role of CEO becomes relevant in managing this issue based of this theory. As an implication, this will determine the approach, policy and execution of top managers in implementing strategies to meet the public demands for environmental contribution to show that company has commitment for sustainable development.

\subsection{Theoretical Framework}

This study investigates the effect of CEO's gender (GENDER), age (AGE), nationality (NAT), expertise that consist of education level (EDU_LVL), education major (EDU_MAJOR) and international education (INT_EDU), and international experience (INT_EXP) on environmental 
performance (GRI). We also control for several factors such as bank size (SIZE), and reporting period (SFR). The research framework is presented in Figure 1 as follows:

Figure 1: Research Framework

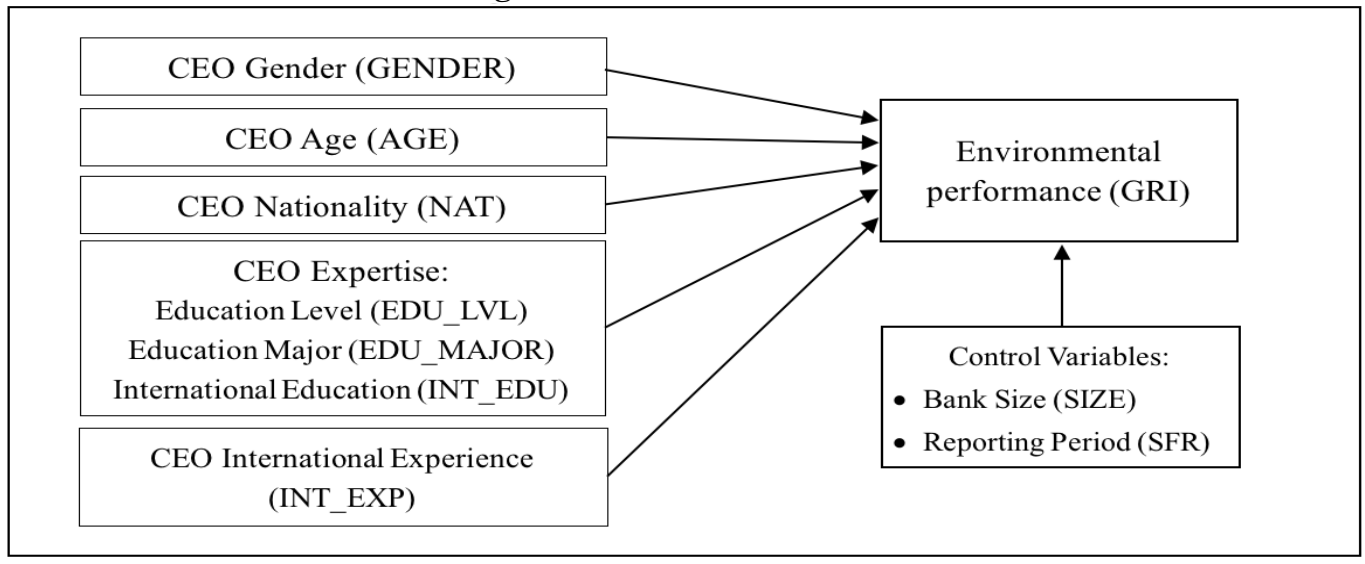

\subsection{Hypothesis Development}

\section{i. CEO Gender on Environmental Performance}

Gender plays a certain role in decision making and the implementation of corporate strategies to achieve certain levels of performance (Huang, 2012). Strategic decisions can be in the form of decision making in environmental performance related policies (Tang et al., 2018). The gender of the CEO may be related to the company's environmental performance. Therefore, in this study, gender is taken as one of the proxies representing the CEO's characteristics. Agency theory explains the relationship between the principal (owner/shareholder) and agent (the manager who manages the company) (Mantysaari, 2010). This theory assumes that there are opportunities for agency problems due to the conflict of interest and differences in access to information (information asymmetry). The principal wants stability in the business concerning laws and government regulations in maintaining the security of the company business.

Business growth and security as parts of maintaining business sustainability are the principal intentions that must be realised by agents. In this case, female agents are generally more sensitive toward environmental issues (Rao \& Tilt, 2016). They are also more effective in pursuing environmentally friendly strategies (Glass et al., 2015). The literature on gender roles in determining the level of environmental involvement tends to refer to the argument that women have a higher sensitivity and attention toward environmental issues (Prabowo et al., 2017; Huang, 2012; Manner, 2010) and are more likely to report related activities to stakeholders (Sundarasen, et al., 2016). Environmental performance is a part that supports the sustainability of a company. This argument is supported by the findings from Manner (2010) which indicates that companies with female CEOs tend to have higher environmental performance scores. In this study, women are expected to build awareness by paying attention to environmental sustainability issues and the sustainability of the resource and financial allocations. Research by Prabowo et al. (2017), Huang 
(2012), and Manner (2010) find that the CEO's gender (female) positively influences environmental performance. Therefore, the hypothesis in this study is as follow:

\section{$\mathbf{H}_{1}$ : Female CEO has a positive effect on environmental performance. \\ ii. CEO Age on Environmental Performance}

Age basically has influence on someone's mindset and awareness. In the case of CEO and environmental performance, age will affect CEO's mindset in decision making process concerning environmental-related issues. Previous studies argue that CEO with younger age will pay more attention to the environmental issues around the company. Valente and Atkinson (2019) mentions that the majority of millennials do believe that business should help achieve sustainable development. Several studies suggest that young CEOs generally get a lot of new insights from the outside world about new and contemporary business issues (Prabowo et al., 2017; Kang, 2016; Manner, 2010). Conflicts can also arise due to the age differences between agents and principals. Younger CEOs tend to pay more attention to issues that occur in the environment. Sometimes, this will lead to different policies and views between the young and the older CEOs.

Younger CEOs are more likely to adopt policies that pay more attention to environmental issues due to higher awareness. They collected more knowledge on environmental issues from the outside which form their character into the innovative leader, especially on the awareness of the importance of environmental responsibility. Further, it will increase their aggressiveness in facing the business issues and challenges (Manner, 2010) including environmental issues. Prior studies by Prabowo et al. (2017) and Manner (2010), find that age negatively affects environmental performance. In addition, McCarthy et al. (2017) demonstrate that companies with younger CEO tend to have higher CSR performance. Based on the arguments above, the hypothesis in this study is as follows:

\section{H2: CEO age has a negative effect on environmental performance.}

\section{iii. CEO Nationality on Environmental Performance}

Indonesia is a developing country. Previous studies in developing countries evidence that the existence of foreign CEO from developed country will increase company's environmental contribution thanks to higher CEO initiatives and awareness. Several studies provide empirical evidence that CEO nationality affects CEO's decision making in dealing with environmental issues (Christmann \& Taylor, 2001; Harjoto et al., 2019; Sarhan et al., 2019). Khan et al. (2019) and Sarhan et al. (2019) stated that foreign directors tend to be able to carry out their roles and functions independently and are able to provide new perspectives from international context. Harjoto et al. (2019) further argued that higher diversity of nationalities in the board of directors would be able to support the shift in the company's focus to be more stakeholder-oriented so that the company's social and environmental performance would also increase. Christmann and Taylor (2001) also find that director's nationality has a positive effect on environmental performance. Foreign directors are more likely to adopt proactive environmental efforts as a result of higher awareness of international environmental requirements and easier access to environmental management information. Therefore, the existence of foreign CEO can be expected to bring positive impact on company's environmental performance. Based on the arguments above, the hypothesis in this study is as follows: 


\section{$\mathbf{H}_{3}$ : CEO nationality has a positive effect on environmental performance.}

\section{iv. CEO Expertise on Environmental Performance}

Individuals also choose to include themselves into different disciplines based on their beliefs, values, personalities, and concerns (Ewert \& Baker, 2001; Smith, 1995). In the context of company's CEO, the field of discipline that a CEO learns can influence their level of awareness in circumstances that are relevant to their discipline. Hence, it will shape their styles, and actions (Amore et al., 2019). Environmental awareness has been recognized as one of the most important CEO qualities (Huang et al., 2019) that can be reflected from CEO education (Meyer, 2015). Many studies suggests that managers with a degree in economics tend to pursue CSR practices less than managers who have degrees in humanities (Manner, 2010). In contrast, CEOs with an education background on humanities tend to take good initiatives regarding social implications and adhere to environmental standards (Rivera \& De Leon, 2005). Furthermore, Davis (1997) find that sociology and psychology are the field of studies that direct managers to consider cooperative decisions more by considering various stakeholders' interest. Thus, CEOs with a degree in environmental studies are expected to adopt more environmental management programs and strategies.

The level and the field of expertise generally affects CEO's decision-making (Amore et al., 2019), especially in dealing with environmental aspects. Environmental expertise is CEO's ability to make a decision concerning environmental issues, in which leads to better environmental performance (Walls \& Berrone, 2017). CEOs who have expertise in social and humanities will improve the company's concern toward the environment (Manner, 2010). Several empirical studies show that academic background affects various levels of individual environmental concern and behaviour (Ewert \& Baker, 2001; Smith, 1995; De Young, 1996; Stern et al., 1995). Graduates majoring in environmental and biological studies seem to be more likely to show greater pro-environmental concern than those majoring in business, economics, and engineering (Smith, 1995; Ewert \& Baker, 2001). This proves that environmental expertise has a positive effect on environmental performance. Based on the arguments above, the hypothesis in this study is as follows:

H4: CEO expertise has a positive effect on environmental performance.

\section{v. CEO International Experience on Environmental Performance}

International work experience is one of the CEO's characteristics that received attention in the literature (Athanassiou \& Nigh, 2000; Carpenter et al., 2001; Gregersen et al., 1998). Employing directors with more international experience will benefit the company in strategic decision-making (Azam et al., 2018). International experience, especially in developed countries, generally provides CEO with more experience in dealing with environmental issues and public demand. This experience will support the CEO to have more environmental initiatives and engagement (Walls $\&$ Berrone, 2017). International experience has been studied in various organisational contexts and is found to influence a company's activities and achievements (Shahab et al., 2019). CEOs with international experience tend to have valuable and unique ideas that are not possessed by CEOs without international experience. When CEO has experience in an international environment, they 
tend to have additional cognitive and social ideas (Carpenter et al., 2001). This is indicated as an increase in human capital.

Le and Kroll (2017) state that more international experience improves CEO's ability in strategic change, including environmental change. Gong (2006) argues that international experience is a major predictor in building legitimacy among corporate stakeholders to create corporate value in the eyes of stakeholders. The legitimacy among stakeholders in the environment can be achieved through social and environmental practices and communication (Du \& Vieira, 2012). International experience is also found to improve the company's global network (Suutari \& Makela, 2007). This provides benefits in dealing with new and difficult social problems. CEOs can use their global network to get advice or assistance in overcoming the problems. Gong (2006) and Du and Vieira (2012) studies find that international experience has a positive effect on environmental performance. Based on the arguments above, the following hypothesis is proposed:

H5: CEO international experience has a positive effect on environmental performance.

\section{METHODOLOGY}

\subsection{Population and Samples}

The population of this study is all commercial banks in Indonesia in 2010-2018. The period is selected as Indonesian business regulators' concern on environmental issues started arising significantly around 2010s by the issuance of the Law Number 32 of 2009, Sustainable and Responsible Investment Index, Sustainability Reporting Award, and OJK Regulation Number 51/POJK.03/2017. Our samples are selected through a purposive sampling technique. Samples are selected based on certain criteria developed based on the research objectives. The sample criteria are: (a) Bank is registered in the Indonesia Financial Service Authority; and (b) Bank publishes accessible annual report. From our sample selection, we finally generate unbalanced panel data with total 911 observations from 103 Indonesian commercial banks.

\subsection{Research Variables}

The independent variables in this study are CEO's gender (GENDER), age (AGE), nationality (NAT), expertise that consist of education level (EDU_LVL), education major (EDU_MAJOR) and international education (INT_EDU), and international experience (INT_EXP), while the dependent variable is environmental performance (GRI) that refers to bank's sustainability reporting practice under GRI Financial Service Sector Disclosure guidelines. We also employ several control variables namely bank size (SIZE), and reporting period (SFR). The measurement of our variables is stated as follows: 
Table 1: Variable Measurement

\begin{tabular}{ll}
\hline \hline \multicolumn{1}{c}{ Variable } & \multicolumn{1}{c}{ Measurement } \\
$\begin{array}{l}\text { Dependent } \\
\text { Independent }\end{array}$ & $\begin{array}{l}\text { GRI Financial Service Sector Disclosure Index, see Appendix } 1 \text { for } \\
\text { details. }\end{array}$ \\
CEO Gender (GENDER) & 1: Female; 0: Male. \\
CEO Age (AGE) & Total number of CEO age in years \\
CEO Nationality (NAT) & 1: Foreign CEO; 0: Indonesian citizenship CEO \\
CEO Expertise & 2: Master or above; 1: Bachelor/Diploma; 0: High school or below \\
- Education Level (EDU_LVL) & 1: Economic/Social/Environment Studies; 0: None of them \\
- Education Major(EDU_MAJOR) & 1: Has foreign degree; 0: Does not have foreign degree \\
- International Education & Number of positions previously held in abroad MNCs \\
(INT_EDU) & \\
CEO International Experience & \\
(INT_EXP) & Log of total assets \\
\hline Control & 1: 2010-2014 reporting period (before OJK Sustainable Finance \\
Bank Size (SIZE) & Roadmap implementation); 0: 2015-2018 reporting period (OJK \\
Reporting Period (SFR) & Sustainable Finance Roadmap implementation stage) \\
\hline \hline
\end{tabular}

\subsection{Data Analysis}

The design of this study is a hypothesis testing that examines the effect of the CEO's gender, age, nationality, expertise, and international experience on bank's environmental performance. A multivariate analysis model is employed to test the effect of the independent variables on the dependent variable. The test is performed with panel data regression analysis. Due to having a set of unbalanced panel data, we perform panel data regression analysis with the help of STATA 14 Statistics Software thanks to its capability in dealing with unbalanced panel data by excluding observations with missing values and focusing on complete case analysis. The regression model for hypothesis testing is formulated as follows:

$$
\begin{aligned}
G R I= & \beta 0+\beta 1 G E N D E R_{i t}+\beta 2 A G E_{i t}+\beta 3 N A T_{i t}+\beta 4 E D U_{L} L V L_{i t} \\
& +\beta 5 E D U_{-} M A J O R_{i t}+\beta 6 I N E_{-} E D U_{i t}+\beta 7 I N T \_E X P_{i t} \\
& +\beta 8 S I Z E_{i t}+\beta 9 S F R_{i t}+e
\end{aligned}
$$

Information:

$\begin{array}{ll}\text { GRI } & : \text { Environmental performance } \\ \text { GENDER } & : \text { CEO gender } \\ \text { AGE } & : \text { CEO age } \\ \text { NAT } & : \text { CEO nationality } \\ \text { EDU_LVL } & : \text { CEO education level } \\ \text { EDU_MAJOR } & : \text { CEO education major } \\ \text { INT_EDU } & : \text { CEO education level } \\ \text { INT_EXP } & : \text { CEO international experience } \\ \text { SIZE } & : \text { Bank size }\end{array}$




$\begin{array}{ll}\text { SFR } & : \text { Reporting period } \\ \beta 0 & : \text { Constant } \\ \beta 1-\beta 9 & : \text { Regression coefficient } \\ \text { e } & : \text { Error standard }\end{array}$

\section{RESULTS AND DISCUSSION}

\subsection{Descriptive Statistics and Correlation}

Data analysis is performed by examining descriptive statistics and variable correlation as initial step. The main analysis for hypotheses testing is performed with panel data regression analysis. The result of descriptive statistics is presented in Table 2 as follows:

Table 2: Descriptive Statistics

\begin{tabular}{|c|c|c|c|c|c|}
\hline \multicolumn{6}{|c|}{ Panel A: Continuous Variables } \\
\hline Variable & Obs & Mean & Std.Dev. & Min & Max \\
\hline GRI & 870 & 0.053 & 0.132 & 0 & 0.684 \\
\hline AGE & 781 & 54.576 & 5.744 & 40 & 74 \\
\hline EDU_LVL & 839 & 1.186 & 0.687 & 0 & 2 \\
\hline INT_EXP & 779 & 0.339 & 0.841 & 0 & 5 \\
\hline SIZE & 872 & 13.053 & 0.729 & 11.123 & 15.113 \\
\hline \multicolumn{6}{|c|}{ Panel B: Dummy Variables } \\
\hline \multirow{2}{*}{ Variable } & \multirow{2}{*}{ Obs } & \multicolumn{2}{|c|}{ Dummy 1} & \multicolumn{2}{|c|}{ Dummy 0} \\
\hline & & Frequency & Percentage & Frequency & Percentage \\
\hline GENDER & 863 & 53 & $6.1 \%$ & 810 & $93.9 \%$ \\
\hline NAT & 855 & 161 & $18.8 \%$ & 694 & $81.2 \%$ \\
\hline EDU_MAJOR & 843 & 710 & $84.2 \%$ & 133 & $15.8 \%$ \\
\hline INT_EDU & 835 & 384 & $46 \%$ & 451 & $54 \%$ \\
\hline SFR & 911 & 408 & $44.8 \%$ & 503 & $55.2 \%$ \\
\hline \multicolumn{6}{|c|}{$\begin{array}{l}\text { Information: } \\
\text { GRI = Environmental performance; GENDER = CEO gender; AGE = CEO age; } \\
\text { NAT = CEO nationality; EDU_LVL = CEO education level; EDU_MAJOR = CEO education major; } \\
\text { INT_EDU = CEO international education; INT_EXP = CEO international experience; } \\
\text { SIZE = Bank size; SFR = reporting period. }\end{array}$} \\
\hline
\end{tabular}

Descriptive statistics result as presented in Table 2 shows that environmental performance of Indonesian banks during 2010-2018 based on GRI Financial Service Sector Disclosure (FSSD) is still low at 5.3 percent overall. The lowest score, that is also the mode, is 0 as most of the banks have not adopted environmental practice in accordance with GRI FSSD guidelines. Meanwhile, the highest score is at $68.4 \%$ in which there is a bank that have adopted $68.4 \%$ sustainability activities following GRI FSSD guidelines. We further examine the trend of total number of banks that engage in environmental activities based on GRI during 2010-2018 as presented in Figure 2. We discover positive trend in terms of banks' participation in which the number continuously increases. Significant improvement started from 2014, the same year when sustainable finance 
roadmap is issued. Thus, it can be argued that the issuance of sustainable finance roadmap encourages banks to participate in environmental activities.

Figure 2: The Trend of Indonesian Bank's Environmental Engagement Based on GRI

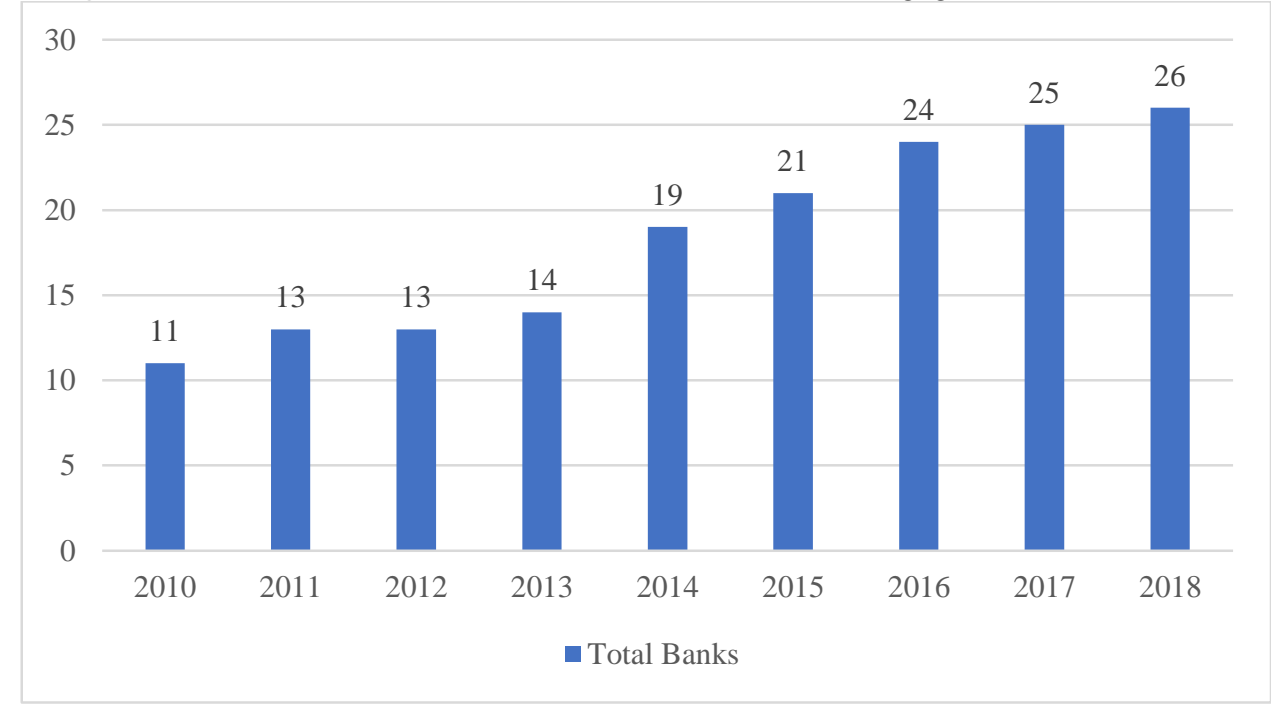

As for CEO characteristics, the average CEO age is 54 years. CEOs of Indonesian banks in 20102018 is dominated with male and Indonesian citizenship. Related to CEO expertise, most CEOs have bachelor level education, economic/social/environmental major, and achieve the degree in domestic universities. The average of CEO international experience is 0.339 , indicating that there are limited number of CEOs with international experience. The highest international experience is 5, meaning that the CEO ever held managerial position in five countries. Meanwhile, the statistics of bank size of control variables shows average value of 13.053 that is around 11 trillion rupiahs of total assets. Reporting period variable also reveals that our samples consist of 408 bank observations in during sustainable finance roadmap implementation in 2015-2019 and the rest is 503 observations before the roadmap observation in 2010-2014. In addition, we further analyse the correlation among research variables in which the result is presented in Table 3. 
Table 3: Correlation Matrix

\begin{tabular}{|c|c|c|c|c|c|c|c|c|c|c|}
\hline $\begin{array}{l}\frac{0}{0} \\
\frac{\pi}{\pi} \\
\frac{\pi}{\nu}\end{array}$ & 웡 & 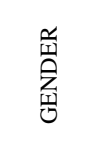 & 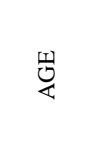 & $\begin{array}{l}\mathrm{J}^{\prime} \\
\mathrm{D}^{\prime} \\
\text { 至 }\end{array}$ & 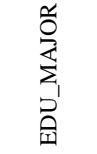 & $\begin{array}{l}\text { 只 } \\
\text { 点 } \\
\underline{\mathbf{Z}}\end{array}$ & 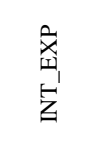 & 案 & 楚 & 站 \\
\hline GRI & 1.000 & & & & & & & & & \\
\hline GENDER & 0.050 & 1.000 & & & & & & & & \\
\hline AGE & 0.008 & -0.118 & 1.000 & & & & & & & \\
\hline EDU_LVL & -0.025 & -0.138 & -0.054 & 1.000 & & & & & & \\
\hline $\begin{array}{c}\text { EDU_MAJ } \\
\text { OR }\end{array}$ & 0.121 & 0.028 & -0.039 & 0.253 & 1.000 & & & & & \\
\hline INT_EDU & 0.087 & 0.040 & -0.123 & 0.112 & 0.077 & 1.000 & & & & \\
\hline INT_EXP & 0.205 & -0.079 & -0.014 & -0.215 & -0.017 & 0.382 & 1.000 & & & \\
\hline NAT & -0.003 & -0.106 & -0.086 & -0.113 & -0.070 & 0.404 & 0.555 & 1.000 & & \\
\hline SIZE & 0.663 & -0.101 & 0.127 & -0.043 & 0.076 & 0.139 & 0.299 & 0.098 & 1.000 & \\
\hline SFR & 0.142 & -0.022 & 0.109 & 0.018 & 0.021 & 0.063 & 0.040 & 0.030 & 0.153 & 1.000 \\
\hline
\end{tabular}

\subsection{Panel Data Regression Analysis Result}

The main analysis is conducted with panel data regression analysis to examine the effect of CEO's gender, age, nationality, expertise, and international experience on bank's environmental performance, with bank size and reporting period as control variables. In our test, we also conduct sub-sample analysis divided into listed and non-listed banks. The result shows that the best estimation is fixed effect for all examination. Due to the incompleteness of several data in independent variables, the regression performed results in 694 total observations. Specifically, the total observations are 694 in all banks examination, 379 in listed banks examination, and 315 in non-listed banks examination. All of the regression models have proper model fitness, both in terms of coefficient of determination statistics and F-statistics test, and thus can be employed as a basis for hypotheses testing. The result of panel data regression is presented in Table 4 as follows:

Table 4: Panel Data Regression Analysis Result

\begin{tabular}{lrrrrrrrrr}
\hline \hline \multirow{2}{*}{$\begin{array}{c}\text { Dependent } \\
\text { Variable: GRI }\end{array}$} & \multicolumn{3}{c}{ All banks } & \multicolumn{3}{c}{ Listed Banks } & \multicolumn{2}{c}{ Non-Listed Banks } \\
\cline { 2 - 10 } & Coef. & $\begin{array}{c}\text { t- } \\
\text { value }\end{array}$ & $\begin{array}{c}\text { p- } \\
\text { value }\end{array}$ & \multicolumn{1}{c}{ Coef. } & $\begin{array}{c}\text { t- } \\
\text { value }\end{array}$ & $\begin{array}{c}\text { p- } \\
\text { value }\end{array}$ & Coef. & $\begin{array}{c}\text { t- } \\
\text { value }\end{array}$ & $\begin{array}{c}\text { p- } \\
\text { value }\end{array}$ \\
\hline GENDER & 0.014 & 0.62 & 0.532 & -0.003 & -0.07 & 0.948 & 0.003 & 0.16 & 0.871 \\
AGE & 0.001 & 0.96 & 0.335 & 0.002 & 1.35 & 0.176 & 0.000 & -0.56 & 0.579 \\
NAT & $\mathbf{- 0 . 0 6 6}$ & $\mathbf{- 2 . 8 7}$ & $\mathbf{0 . 0 0 4}$ & $\mathbf{- 0 . 0 7 4}$ & $\mathbf{- 2 . 2 5}$ & $\mathbf{0 . 0 2 5}$ & -0.02 & -0.34 & 0.736 \\
EDU_LVL & 0.015 & 1.51 & 0.131 & $\mathbf{0 . 0 4 5}$ & $\mathbf{2 . 3 1}$ & $\mathbf{0 . 0 2 2}$ & -0.01 & -1.19 & 0.234 \\
EDU_MAJOR & -0.004 & -0.31 & 0.759 & -0.009 & -0.38 & 0.703 & 0.008 & 0.57 & 0.567 \\
INT_EDU & $\mathbf{- 0 . 0 2 6}$ & $\mathbf{- 2 . 3 3}$ & $\mathbf{0 . 0 2 0}$ & $\mathbf{- 0 . 0 4 5}$ & $\mathbf{- 2 . 2 3}$ & $\mathbf{0 . 0 2 7}$ & -0.000 & -0.48 & 0.632 \\
INT_EXP & $\mathbf{0 . 0 2 7}$ & $\mathbf{1 . 8 1}$ & $\mathbf{0 . 0 7 0}$ & $\mathbf{0 . 0 5 3}$ & $\mathbf{2 . 4 2}$ & $\mathbf{0 . 0 1 6}$ & -0.02 & -1.27 & 0.206 \\
SIZE & $\mathbf{0 . 0 6 2}$ & $\mathbf{3 . 3 8}$ & $\mathbf{0 . 0 0 1}$ & $\mathbf{0 . 0 5 7}$ & $\mathbf{1 . 8 7}$ & $\mathbf{0 . 0 6 2}$ & $\mathbf{0 . 0 5 8}$ & $\mathbf{3 . 4 9}$ & $\mathbf{0 . 0 0 1}$ \\
SFR & $\mathbf{0 . 0 3 2}$ & $\mathbf{4 . 3 4}$ & $\mathbf{0 . 0 0 0}$ & $\mathbf{0 . 0 4 4}$ & $\mathbf{3 . 5 4}$ & $\mathbf{0 . 0 0 0}$ & $\mathbf{0 . 0 1 7}$ & $\mathbf{2 . 5 7}$ & $\mathbf{0 . 0 1 1}$ \\
Constant & -0.808 & -3.39 & 0.001 & -0.787 & -1.98 & 0.048 & -0.69 & -3.25 & 0.001 \\
\hline
\end{tabular}




\begin{tabular}{lccc} 
Total Obs. & 694 & 379 & 315 \\
R-squared & 0.148 & 0.184 & 0.164 \\
F-test & 11.646 & 8.193 & 5.773 \\
Prob. & 0.000 & 0.000 & 0.000 \\
\hline
\end{tabular}

\section{Information:}

GRI $=$ Environmental performance; GENDER $=$ CEO gender; $\mathrm{AGE}=\mathrm{CEO}$ age;

NAT $=$ CEO nationality; EDU_LVL $=$ CEO education level; EDU_MAJOR = CEO education major;

INT_EDU $=$ CEO international education; INT_EXP $=$ CEO international experience;

SIZE $=$ Bank size; SFR $=$ reporting period.

Our analysis reveals that CEO gender is not a significant determinant of environmental performance in Indonesian commercial banks in all examination scenario in which there are also several studies with the same finding (McCarthy et al., 2017). CEO gender in Indonesian banks probably does not contribute much to determining environmental performance due to the limited number of female CEO in Indonesian banks. CEO age, in all examination scenario, also provides no significant effect in which the point of view of younger and older CEO may be the same regarding environmental issues.

Interestingly, we find that foreign $\mathrm{CEO}$ provides negative effect on environmental performance, similar to Huang's (2013) result. Banks with foreign CEO are less likely to engage in environmental activities that may due to the fact that most foreign CEOs in the samples are also from developing countries. Thus, the mindset and outlook in sustainability is not significantly different from people in developing countries. Kang et al. (2019) even discover that foreign directors from AngloAmerican countries tend to decrease company's CSR involvement. It is argued that they are more shareholder-centered and thus focuses more on strong investor protection mechanisms and widespread recognition of firms as isolated actors and finally decreases CSR involvement. In addition, banks with foreign CEOs in our samples are mostly not listed in the Indonesian Stock Exchange in which these banks have less public pressure and demand to contribute to sustainability. Therefore, these banks have lower environmental performance.

As for CEO expertise, CEO education level positively affects environmental performance in listed banks examination. Meanwhile, the effect is not significant in all banks and non-listed banks examination. This positive effect means that the higher is the level of education, the better is the environmental performance in Indonesian listed banks. Higher education level should increase the CEOs' awareness of environmental issues and thus they can build better environmental strategy, confirming the result from Amore et al. (2019). Education major has no significant effect in all examination. The result proves that having economic / social / environmental background does not motivate CEO in Indonesian banks to contribute more to environmental issues. Several previous studies also find no significant effect such as Huang (2012). Although many universities have paid attention to environmental issues to promote sustainable development and raise students' awareness of the issues, there is no guarantee that it can change students' behaviour (Thomas, 2005).

Surprisingly, we find significant negative effect of CEO international education on environmental performance in all banks and listed banks examination. This CEOs who have never studied at universities abroad have better environmental performance compared to CEOs who have studied at universities abroad. Our result may imply that environmental concern has been developed quite extensively so that it is levelled with international education setting or maybe even higher. This 
result may also come up due to the personality of the CEOs with international education that may has relatively lower environmental concern.

Our analysis provides empirical evidence that CEO international experience demonstrate positive effect on bank's environmental performance in all banks and listed banks examination. CEO international experience (INT_EXP) has a significant positive effect with second-highest contribution to environmental performance. The positive effect implies that the higher international experience that a CEO has, the better is the environmental performance, and conversely, the lower the international experience possessed by a CEO, the lower is the quality of the bank's environmental performance. The finding supports the idea that higher international experience will improve CEO's ability in strategic change (Le \& Kroll, 2017), creating legitimacy in the eyes of stakeholders through environmental performance (Du \& Vieira, 2012; Gong, 2006). As a result, company tends to pursue more environmental practice (Manner, 2010) that will increase their environmental performance (Walls \& Berrone, 2017).

As for the control variables, both bank size and reporting year within sustainable finance roadmap show significant positive effect. Larger banks are more likely to adopt environmental practice, confirming Amidjaya and Widagdo (2019), Dienes et al. (2016), Dilling (2010). Finally, with the significant effect of reporting period, it implies that banks' participation in environmental activities increases since the implementation of sustainable finance roadmap issued by OJK that started from 2015. Despite the increase is not so high, the roadmap implementation at least encourages several banks to participate more in environmental activities.

\section{CONCLUSION}

This study concludes that CEO characteristics affect environmental-related policies in Indonesian banks. This study reveals the relationship between several important CEO variables regarding bank's environmental performance despite having mixed results. The novelty of our findings is that CEO international experience demonstrates positive effect on environmental performance. CEO education level also exhibits positive effect but only in listed banks. Moreover, CEO gender, age, and education background have no significant effect on environmental performance in Indonesian banks while CEO nationality and international education shows negative effect in which these findings do not confirm the majority of previous studies. Unfortunately, the overall environmental performance of Indonesian banks is still low that might be caused by the absence of regulation from Indonesia's Financial Services Authority (OJK) concerning environmental disclosure on the observed data during 2012-2018. The absence of such regulation makes many banks in Indonesia did not implement environmental activities based on GRI guidelines. It is therefore suggested that future research observe bank's environmental performance after the implementation of environmental disclosure policy by OJK to obtain the ideal condition.

Based on our research findings, we suggest OJK to implement higher enforcement of OJK regulation 51/POJK.03/2017 concerning sustainable finance that starts from 2019. With higher enforcement and encouragement from OJK, it can be expected that the banks' participation in environmental protection and sustainable development can be maximized. OJK can achieve this with higher $\mathrm{CEO}$ role and involvement. OJK as the regulator of banking industry and capital market should provide more mandatory seminars and trainings on environmental performance and 
sustainability to companies' CEOs or directors. It is important to build better understandings on environmental protection and sustainability. OJK can also set higher standards of environmental expertise in $\mathrm{CEO}$ /director qualification test to ensure that newly appointed CEOs and directors in the future have proper knowledge of environmental protection so that the company can contribute more to environmental protection and sustainability.

\section{ACKNOWLEDGEMENT}

This paper was presented at the ICESD Conference 2020 organized by the Doctoral Program in Environmental Science, Universitas Sebelas Maret.

\section{REFERENCES}

Amidjaya, P. G., \& Widagdo, A. K. (2019). Sustainability reporting in Indonesian listed banks: Do corporate governance, ownership structure and digital banking matter?, Journal of Applied Accounting Research, 21(2), 231-247.

Amore, M. D., Bennedsen, M., Larsen, B., \& Rosenbaum, P. (2019). CEO education and corporate environmental footprint. Journal of Environmental Economics and Management, 94, 254273.

Athanassiou, N., \& Nigh, D. (2000). Internationalization, tacit knowledge and the top management teams of MNCs. Journal of International Business Studies, 31(3), 471-487.

Azam, A., Boari, C., \& Bertolotti, F. (2018). Top management team international experience and strategic decision-making. Multinational Business Review, 26(1), 50-70.

Boiral, O., \& Henri, J. F. (2017). Is sustainability performance comparable? A study of GRI reports of mining organizations. Business \& Society, 56(2), 283-317.

Carpenter, M. A., Geletkancz, M. A., \& Sanders, W. G. (2004). Upper echelons research revisited: Antecedents, elements and consequences of top management team composition. Journal of Management, 30(6), 749-778.

Carpenter, M. A., Sanders, W. G., \& Gregersen, H. B. (2001). Bundling human capital with organizational context: The impact of international assignment experience on multinational firm performance and CEO pay. Academy of Management Journal, 44(3), 493-511.

Carr, J. B., \& Brower, R. S. (2000). Principled opportunism: Evidence from the organizational middle. Public Administration Quarterly, 24(1), 109-138.

Christmann, P., \& G. Taylor. (2001). Globalization and the environment: Determinants of firm self-regulation in China. Journal of International Business Studies, 32, 439-458.

David, K., Paul, M., Ongeti, W., Nicholas, L., \& Evans, A. (2012). Upper echelons theory and research: A review of theory and empirical literature 28 years later. Prime Journals of Business Administration and Management, 2(10), 697-703.

Davis, J. H. (1997). Toward a stewardship theory of management. Academy of Management Review, 22(1), 20-47.

De Young, R. (1996). Some psychological aspects of reduced consumption behavior: The role of intrinsic satisfaction and competence motivation. Environment \& Behavior, 28(1), 358409. 
Dienes, D., Sassen, R., \& Fischer, J. (2016), What are the drivers of sustainability reporting? A systematic review. Sustainability Accounting, Management and Policy Journal, 7(2), 154-189.

Dilling, P. F. (2010). Sustainability reporting in a global context: What are the characteristics of corporations that provide high quality sustainability reports an empirical analysis. International Business \& Economics Research Journal (IBER), 9(1), 19-30.

Djajadikerta, H. G., \& Trireksani, T. (2012). Corporate social and environmental disclosure by Indonesian listed companies on their corporate web sites. Journal of Applied Accounting Research, 13(1), 21-36.

Du, S., \& Vieira, E. T. (2012). Striving for legitimacy through corporate social responsibility: Insights from oil companies. Journal of Business Ethics, 110(4), 413-427.

Elkington, J. (1997). Cannibals with forks, the triple bottom line of twentieth century business. UK: Capstone.

Ewert, A., \& Baker, D. (2001). Standing for where you sit: An exploratory analysis of the relationship between academic major and environment beliefs. Environment and Behavior, 33(1), 687-707.

Fama, E. F. (1980). Agency problems and the theory of the firm. Journal of Political Economy, 88(2), 288-307.

Fama, E. F., \& Jensen, M. C. (1983). Separation of ownership and control. Journal of Law and Economics, 26(2), 301-325.

Fatemi, A. M. \& Iraj, F. J. (2013). Sustainable finance: A new paradigm. Global Finance Journal, 24(2), 101-113.

Feng, H. C., \& Ru, L. B. (2019). Analysis of sustainable development path for green finance: A case study of China. In Green Finance for Sustainable Global Growth (pp. 62-83). Pennsylvania: IGI Global.

Fernando, P. M. P., \& Fernando, K. S. D. (2017). Study of green banking practices in the Sri Lankan context: a critical review. In Selected Papers from the Asia-Pacific Conference on Economics \& Finance (APEF 2016) (pp. 125-143). Singapore: Springer.

Friedman, M. (2007). The Social Responsibility of Business Is to Increase Its Profits. Corporate Ethics and Corporate Governance, Berlin: Springer.

Glass, C., Cook, A., \& Ingersoll, A. R. (2015). Do women leaders promote sustainability? Analyzing the effect of corporate governance composition on environmental performance. Business Strategy and the Environment, 25(7), 495-511.

Gong, Y. (2006). The impact of subsidiary top management team national diversity on subsidiary performance: Knowledge and legitimacy perspectives. Management International Review, 46(6), 771-790.

Gregersen, H. B., Morrison, A., \& Black, S. (1998). Developing leaders for the global frontier. Sloan Management Review, 40(1), 21-32.

Gunawan, J. (2015). Corporate social disclosures in Indonesia: Stakeholders' influence and motivation. Social Responsibility Journal, 11(3), 535-552.

Hambrick, D. C., \& Mason, P. A. (1984). Upper echelons: The organization as a reflection of its top managers. Academy of management review, 9(2), 193-206.

Harjoto, M. A., Laksmana, I., \& Yang, Y. W. (2019). Board nationality and educational background diversity and corporate social performance. Corporate Governance, 19(2), 217-239. 
Huang, Q., Chen, X., Zhou, M., Zhang, X., \& Duan, L. (2019). How does CEO's environmental awareness affect technological innovation? International Journal of Environmental Research and Public Health, 16(2), 1-16.

Huang, S. K. (2012). The impact of CEO characteristics on corporate sustainable development. Corporate Social Responsibility and Environmental Management, 20(4), 234-244.

Jensen, M. C., \& Meckling, W. H. (1976). Theory of The Firm: Managerial Behavior, Agency Costs and Ownership Structure. Journal of Financial Economics, 3(4), 305-360.

Jensen, M. C. (1986). Agency costs of free cash flow, corporate finance, and takeovers. The American Economic Review, 76(2), 323-329.

Kang, J. (2016). Labor market evaluation versus legacy conservation: What factors determine retiring CEOs' decisions about long-term investment?. Strategic Management Journal, 37(2), 389-405.

Kang, Y. S., Huh, E., \& Lim, M. H. (2019). Effects of foreign directors' nationalities and director types on corporate philanthropic behavior: Evidence from Korean firms. Sustainability, 11(11), 3132.

Khan, I., Khan, I., \& Senturk, I. (2019). Board diversity and quality of CSR disclosure: evidence from Pakistan. Corporate Governance: The International Journal of Business in Society, 19(6), 1187-1203.

Kim, B., Lee, S., \& Kang, K. H. (2018). The moderating role of CEO narcissism on the relationship between uncertainty avoidance and CSR. Tourism Management, 67, 203-213.

Le, S., \& Kroll, M. (2017). CEO international experience: Effects on strategic change and firm performance. Journal of International Business Studies, 48(5), 573-595.

Lewis, B. W., Walls, J. L., \& Dowell, G. W. S. (2014). Difference in degrees: CEO characteristics and firm environmental disclosure. Strategic Management Journal, 35(5), 712-722.

Manner, M. H. (2010). The impact of CEO characteristics on corporate social performance. Journal of business ethics, 93(1), 53-72.

Mantysaari, P. (2010). The law of corporate finance: General principles and EU law, Volume I: Cash flow, risk, agency, information. Berlin: Springer.

McCarthy, S., Oliver, B., \& Song, S. (2017). Corporate social responsibility and CEO confidence. Journal of Banking \& Finance, 75, 280-291.

Meyer, A. (2015). Does education increase pro-environmental behavior? Evidence from Europe. Ecological Economics, 116, 108-121.

Nelson, J. (2005). Corporate governance practices, CEO characteristics and firm performance. Journal of Corporate Finance, 11(1-2), 197-228.

Peterson, S. J., Galvin, B. M., \& Lange, D. (2012). CEO servant leadership: Exploring executive characteristics and firm performance. Personnel Psychology, 65(3), 565-596.

Prabowo, M. A., Jamin, M., Saputro, D. J., Mufraini, A., \& Agustia, D. (2017). Female executive officers and corporate social responsibility disclosure: evidence from the banking industry in an emerging market. Journal for Global Business Advancement, 10(6), 631-651.

Rao, K., \& Tilt, C. (2016). Board composition and corporate social responsibility: The role of diversity, gender, strategy and decision making. Journal of Business Ethics, 138(2), 327 347.

Richter, U. H., \& Arndt, F. F. (2018). Cognitive processes in the CSR decision-making process: a sensemaking perspective. Journal of Business Ethics, 148(3), 587-602.

Rivera, J., \& De Leon, P. (2005). Chief executive officers and voluntary environmental performance: Costa Rica's certification for sustainable tourism. Policy Science, 38, 107127. 
Sarhan, A. A., Ntim, C. G., \& Al-Najjar, B. (2019). Board diversity, corporate governance, corporate performance, and executive pay. International Journal of Finance and Economics, 24, 761-786.

Sarumpaet, S., Nelwan, M. L., \& Dewi, D. N. (2017). The value relevance of environmental performance: Evidence from Indonesia. Social Responsibility Journal, 13(4), 817-827.

Scholtens, B. (2017). Why finance should care about ecology. Trends in Ecology \& Evolution, 32(7), 500-505.

Scott, W. (2012). Financial accounting theory international. New Jersey: Prentice Hall Inc.

Shahab, Y., Ntim, C., Yugang, C., Ullah, F., Li, H. X., \& Ye, Z. (2019). CEO attributes, sustainable performance, environmental performance, and environmental reporting: New insights from upper echelons perspective. Business Strategy and the Environment. 29(1), 1-16.

Shleifer, A., \& Vishny, R. W. (1986). Large shareholders and corporate control. Journal of Political Economy, 94(3), 461-488.

Siregar, S. V., \& Bachtiar, Y. (2010). Corporate social reporting: empirical evidence from Indonesia Stock Exchange. International Journal of Islamic and Middle Eastern Finance and Management, 3(3), 241-252.

Smith, K. (1995). Does education induce people to improve the environment?. Journal of Public Policy Analysis and Management, 14(4), 599-604.

Sparkes, R. (2002). Socially Responsibility Investment, a Global Revolution. UK: John Wiley \& Sons Ltd.

Stern, P. C., Kalof, L., Dietz, T., \& Guagnano, G. A. (1995). Values, beliefs, and proenvironmental action: Attitude formation toward emergent attitude objects. Journal of Applied Social Psychology, 25, 1611-1636.

Sundarasen, S. D. D., Je-Yen, T., \& Rajangam, N. (2016) Board composition and corporate social responsibility in an emerging market, Corporate Governance, 16(1), 35-53.

Suutari, V., \& Mäkelä, K. (2007). The career capital of managers with global careers. Journal of Managerial Psychology, 22(7), 628-648.

Tang, Y., Mack, D. Z., \& Chen, G. (2018). The differential effects of CEO narcissism and hubris on corporate social responsibility. Strategic Management Journal, 39(5), 1370-1387.

Tara, K., Singh, S., \& Kumar, R. (2015). Green banking for environmental management: a paradigm shift. Current World Environment, 10(3), 1029-1038.

Thomas, T. (2005). Are business students buying it? A theoretical framework for measuring attitudes toward the legitimacy of environmental sustainability. Business Strategy and the Environment, 14(3), 186-197.

Valente, A., \& Atkinson, D. (2019). Sustainability in business: A millennials' perspective. Journal of Modern Accounting and Auditing, 15(6), 293-304.

Volz, U. (2018). Fostering green finance for sustainable development in Asia. ADBI Working Paper No. 814. Tokyo: Asian Development Bank Institute (ADBI).

Walls, J. L., \& Berrone, P. (2017). The power of one to make a difference: How informal and formal CEO power affect environmental sustainability. Journal of Business Ethics, 145(2), 293-308.

Zhou, M. M., \& Panbunyuen, P. (2008). The Association Between Board Composition and Different Types of Voluntary Disclosure. A Quantitative study of Chinese and Swedish Listed Companies, 16(3), 555-583.

Zuraik, A., \& Kelly, L. (2019). The role of CEO transformational leadership and innovation climate in exploration and exploitation. European Journal of Innovation Management, 22(1), 84104. 


\section{Appendix 1: Bank's Environmental Performance Index Measurement} Adopting from GRI Financial Service Sector Disclosure

\begin{tabular}{|c|c|}
\hline $\begin{array}{l}\text { GRI-G4 } \\
\text { Indicator }\end{array}$ & Description \\
\hline \multicolumn{2}{|c|}{ Economic Category } \\
\hline G4-DMA & Disclosure of management approach in dealing with economic development issues \\
\hline EC1 & Direct economic value generated and distributed \\
\hline \multicolumn{2}{|c|}{ Environment Category } \\
\hline EN15 & Direct greenhouse gas (GHG) emissions (scope 1) \\
\hline EN16 & Energy (scope 2) \\
\hline EN17 & Other indirect impact (scope 3) \\
\hline EN23 & Waste by type and disposal method \\
\hline \multicolumn{2}{|c|}{ Social Category } \\
\hline \multicolumn{2}{|c|}{ Sub-Category: Labor } \\
\hline G4-DMA & Disclosure of management approach in dealing with labor issue \\
\hline \multicolumn{2}{|c|}{ Sub-Category: Human Rights } \\
\hline HR1 & $\begin{array}{l}\text { Investment agreements and contracts including human rights clauses or underwent } \\
\text { human rights screening }\end{array}$ \\
\hline \multicolumn{2}{|c|}{ Sub-Category: Society } \\
\hline FS13 & Access points in low-populated or economically disadvantaged areas by type \\
\hline FS14 & Initiatives to improve access to financial services for disadvantaged people \\
\hline \multicolumn{2}{|c|}{ Sub-Category: Product Responsibility } \\
\hline \multicolumn{2}{|c|}{ Aspect: Product and Service Labeling } \\
\hline G4-DMA & Disclosure of management approach in product and service development aspect \\
\hline \multicolumn{2}{|c|}{ Aspect: Product Portfolio } \\
\hline G4-DMA & Disclosure of management approach in product portfolio aspect \\
\hline FS6 & $\begin{array}{l}\text { Percentage of the portfolio for business lines by specific region, size (e.g. } \\
\text { micro/SME/large) and by sector. }\end{array}$ \\
\hline FS7 & $\begin{array}{l}\text { Monetary value of products and services designed to deliver a specific social benefit } \\
\text { for each business line broken down by purpose. }\end{array}$ \\
\hline FS8 & $\begin{array}{l}\text { Monetary value of products and services designed to deliver a specific environmental } \\
\text { benefit for each business line broken down by purpose. }\end{array}$ \\
\hline \multicolumn{2}{|r|}{ 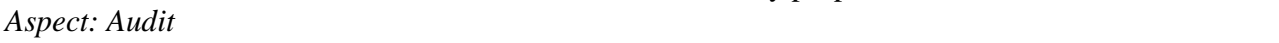 } \\
\hline G4-DMA & Disclosure of management approach in dealing with audit issue \\
\hline \multicolumn{2}{|c|}{ Aspect: Active Ownership } \\
\hline G4-DMA & Disclosure of management approach in active ownership aspect \\
\hline FS10 & $\begin{array}{l}\text { Percentage and number of companies held in the institution portfolio with which the } \\
\text { reporting organization has interacted on environmental or social issues. }\end{array}$ \\
\hline FS11 & $\begin{array}{l}\text { Percentage of assets subject to positive and negative environmental or social } \\
\text { screening. }\end{array}$ \\
\hline
\end{tabular}

